\title{
PENYELENGGARAAN RUPS MELALUI MEDIA ELEKTRONIK TERKAIT KEWAJIBAN NOTARIS MELEKATKAN SIDIK JARI PENGHADAP
}

\author{
Amelia Sri Kusuma Dewi \\ Fakultas Hukum Universitas Brawijaya \\ Jl. MT. Haryono 169 Malang \\ Email: amelia_fhub@yahoo.co.id
}

\begin{abstract}
This research aims to analyze existing norms conflict between Article 16 Paragraph (1) cof Act No. 2 of 2014 on the Amendment Act No. 30 of 2004 concerning Notary which provides that the Notary required to attach the fingerprint of the parties facing the Minuta Deed, and Article 77 of Act No. 40 of 2007 on Limited Liability Company which provides that the Annual General Meeting of Shareholders (AGMS) through media teleconference, videoconference, or other means of electronic media. It also examines the juridical implications of the Notary and Acts of the AGMS through electronic media if the Notary does not fulfill the obligation to attach the fingerprint of the parties facing the Minuta Deed. To answer the above norm conflict, the type of research conducted by researchers is a normative juridical research using the statute approach and conceptual approach. The results of this research, that there is a conflict of norms in the form of obscurity norm, disharmony and emptiness norm in the relevant legislation. Regarding the juridical implications of the notary when not fulfilling the obligation to attach the fingerprint of the parties facing the Minuta Deed, then the notary may be subject to sanctions pursuant to Article 16, paragraph (11) of Act No. 2 of 2014 on the Amendment of Act No. 30 of 2004 on the Notary. As against the deed of the AGMS, fingerprint embedding function within minutes of notarial deed is not a legal action to determine the validity or authenticity of the certificate, but only serves to ensure the correctness identity of the facing parties.
\end{abstract}

Key words: general meeting of shareholders, electronic media, fingerprints, minuta deed

\begin{abstract}
Abstrak
Penelitian ini bertujuan menganalisa konflik norma yang ada antara Pasal 16 Ayat (1) huruf c Undang-undang Nomor 2 Tahun 2014 tentang Perubahan Undang-undang Nomor 30 tahun 2004 tentang Jabatan Notaris yang mengatur bahwa Notaris wajib untuk melekatkan sidik jari penghadap pada Minuta Akta, demikian dengan Pasal 77 Undang-undang Nomor 40 tahun 2007 tentang Perseroan Terbatas (UUPT) yang mengatur bahwa penyelenggaraan Rapat Umum Pemegang Saham (RUPS) melalui media telekonferensi, video konferensi, atau sarana media elektronik lainnya. Selain itu juga mengkaji implikasi yuridis terhadap Notaris dan akta RUPS melalui media elektronik apabila Notaris tidak memenuhi kewajiban untuk melekatkan sidik jari penghadap pada minuta akta. Untuk menjawab konflik norma tersebut di atas, jenis penelitian yang dilakukan oleh peneliti adalah penelitian yuridis normatif dengan menggunakan pendekatan statute approach (pendekatan perUndang-undangan) dan conceptual approach (pendekatan konsep). Hasil penelitian, bahwa terjadi konflik norma berupa kekaburan norma, disharmonisasi maupun kekosongan norma di dalam peraturan perUndang-undangan terkait. Mengenai implikasi yuridis terhadap Notaris apabila tidak memenuhi kewajiban untuk
\end{abstract}


melekatkan sidik jari penghadap pada minuta akta, maka Notaris dapat dikenai sanksi sesuai pasal 16 ayat (11) Undang-undang Nomor 2 Tahun 2014 Tentang Perubahan Atas Undangundang Nomor 30 Tahun 2004 Tentang Jabatan Notaris. Sedangkan terhadap akta RUPS, fungsi melekatkan sidik jari dalam minuta akta Notaris bukan suatu tindakan hukum dalam menentukan keabsahan atau otentisitas dari akta tersebut melainkan hanya berfungsi untuk menjamin kebenaran identitas penghadap.

Kata kunci: rapat umum pemegang saham (RUPS), media elektronik, sidik jari, minuta akta

\section{Latar Belakang}

Manusia sebagai homo sapien diberikan kemampuan untuk berkomunikasi dalam mengatasi berbagai masalah dalam lingkungannya. Kemampuan mereka tidak hanya dalam lingkaran kecil kekerabatan, tetapi meluas hingga lintas batas negara. Tata cara komunikasi yang dilakukan manusia memiliki riwayat tumbuh kembang yang panjang dan beraneka ragam. Hal ini dimulai sejak zaman prasejarah sampai era teknologi satelit dewasa ini.

Proses dalam melakukan penyampaian maksud dan tujuan untuk menyamakan kehendak itu dapat dilakukan secara langsung (face to face) atau menggunakan sarana. Alat bantu (teknologi) dimanfaatkan sebagai sarana untuk komunikasi jarak jauh Sarana itu dimulai dengan cara yang sederhana, seperti media asap sampai dengan teknologi canggih yang dapat berbentuk suara, gambar, tanda, kode, signal, atau intelegensi, baik yang melalui kabel, tanpa kabel atau sistem elektronik lainnya. Telekomunikasi memberikan akses mengenai pengiriman, pemancaran dan atau penerimaan tanda-tanda, signal, tulisan, gambar dan suara atau informasi melalui kawat (kabel), radio, optik atau sistem elektromagnetik lainnya. Perkembangan dunia telekomunikasi mengalami perluasaan wilayah dengan dipergunakan internet sebagai sarana komunikasi. Percepatan inovasi sekarang dimungkinkan karena terintegrasinya seluruh kemampuan berpikir dan daya imajinasi manusia ke dalam sebuah jaringan internet. Jaringan internet menjadi semacam jembatan penghubung telepatis dari manusia ke manusia lainnya dengan kecepatan cahaya menembus batas waktu dan batas negara.

Teknologi Informasi memegang peranan yang penting, baik di masa kini atau masa yang akan datang. Teknologi informasi diyakini membawa keuntungan dan kepentingan yang besar bagi negara-negara di dunia. Ada banyak hal yang membuat teknologi informasi begitu penting dan hal itu dikarenakan bahwa teknologi informasi memacu pertumbuhan ekonomi dunia. Menurut Edmon Makarim², terdapat beberapa hal yang perlu diperhatikan terkait Perluasan Teknologi yang terjadi, yaitu:

1 Rachmadi Usman, Dimensi Hukum Perseroan Terbatas, Alumni, Bandung, 2004, hlm. 48.

2 Edmon Makarim, Pengantar Hukum Telematika, RajaGrafindo Persada, Jakarta, 2007, hlm. 8. 
1) Teknologi terdiri dari informasi yang mampu mengaplikasikan semua tahapan dari perencanaan, organisasi, dan operasi suatu industri atau perusahaan (komersial) dengan segala aktifitasnya.

2) Teknologi mempunyai kontribusi untuk membuat setiap tahapan yang mencakup perencanaan, organisasi dan operasi kegiatan suatu industri atau perusahaan; maka teknologi tidak hanya terdiri dari scientific knowledge, tetapi pengetahuan bisnis atau organisasi.

3) Teknologi bisa berupa teknologi yang berwujud (bertubuh) dan tidak berwujud.

Informasi dan teknologi komunikasi mempengaruhi berbagai aspek kehidupan masyarakat, aspek ekonomi, sosial, budaya. Perkembangan internet telah membawa pengaruh yang besar dalam segala aspek kehidupan manusia, dan dipakai hampir pada semua kegiatan. Perkembangan ini membawa konsekuensi yang penting serta mempengaruhi lalu lintas hukum. ${ }^{3}$

Seiring dengan perkembangan masyarakat dan teknologi, semakin lama manusia semakin banyak menggunakan alat teknologi digital, termasuk dalam berinteraksi antar sesamanya. Perkembangan teknologi digital yang semakin pesat, maka tidak sepantasnya lagi dipersyaratkan suatu tatap muka di antara pihak yang melakukan kontrak, tetapi cukup memakai internet. ${ }^{4}$

Pasal 77 Undang-undang Nomor 40 tahun 2007 tentang Perseroan Terbatas (UUPT), mengakomodasi perkembangan teknologi informasi. Ketentuan Pasal 77 UUPT mengatur bahwa Rapat Umum Pemegang Saham (RUPS) dapat juga dilakukan melalui media telekonferensi, video konferensi, atau sarana media elektronik lainnya yang memungkinkan semua peserta RUPS saling melihat dan mendengar secara langsung serta berpartisipasi dalam rapat.

Pemanfaatan kecanggihan teknologi ini memungkinkan para pemegang saham perusahaan tidak harus bertatap muka secara langsung atau face to face tapi bertatap muka dengan media elektronik yang saling dapat berhubungan seperti layaknya bertatap muka secara langsung. Tujuan yang akan dicapai dalam sebuah rapat tentunya akan membahas tentang sesuatu hal yang berkaitan dengan perusahaan atau Perseroan Terbatas itu sendiri. Kemajuan teknologi informasi ini sangat mempermudah selain lebih efisien juga efektif.

Undang-undang Nomor 11 Tahun 2008 tentang Informasi dan Transaksi Elektronik (UUITE) dengan cakupan meliputi globalisasi, perkembangan teknologi informasi, dan keinginan untuk mencerdaskan kehidupan bangsa. Undang-undang Informasi dan Transaksi Elektronik (UUITE) mengatur berbagai perlindungan hukum atas kegiatan yang memanfaatkan internet sebagai medianya, baik transaksi maupun pemanfaatan informasinya. Pada UUITE

3 I.G. Rai Widjaya, Hukum Perseroan Terbatas (Edisi Revisi), Megapoint Kesant Blanc, Jakarta, 2002, hlm. 82.

4 Munir Fuady, Perseroan Terbatas Paradigma Baru, Citra Aditya Bhakti, Bandung, 2002, hlm. 28. 
ini juga diatur berbagai ancaman hukuman bagi kejahatan melalui internet. UUITE mengakomodir kebutuhan para pelaku bisnis di internet dan masyarakat pada umumnya guna mendapatkan kepastian hukum, dengan diakuinya bukti elektronik dan tanda tangan digital sebagai bukti yang sah di pengadilan.

Dampak yang ditimbulkan adalah bahwa ketentuan UUPT mensyarakatkan bahwa setiap perubahan yang berhubungan dengan Anggaran Dasar dari Perseroan Terbatas itu harus dibuatkan risalah rapat yang harus dituangkan dalam akta otentik, yaitu akta notaris. Hambatan yang nyata dari proses kecanggihan teknologi ini adalah bahwa data yang dihasilkan dari sebuah RUPS dengan menggunakan mekanisme elektronik tentu saja menghasilkan data elektronik pula.

Ada pandangan yang berbeda dalam menganalisa sebuah dokumen elektronik jika hal itu dikaitkan dengan suatu akta otentik. Ada yang berpendapat bahwa aturan yang terdapat pada Pasal 77 UUPT tersebut di atas bertentangan dengan Pasal 1 ayat (7) Undangundang Nomor 30 tahun 2004 tentang Jabatan Notaris yang telah diperbaharui oleh Undang-undang Nomor 2 Tahun 2014 tentang Perubahan Undang-undang Nomor 30 tahun 2004 tentang Jabatan Notaris, bahwa yang dimaksud akta notaris adalah akta otentik yang dibuat oleh atau dihadapan Notaris menurut bentuk dan tata cara yang ditetapkan dalam Undang-undang ini, sedangkan pengertian akta otentik berdasarkan pasal 1868 KUH Perdata adalah suatu akta yang di dalam bentuk yang ditentukan oleh Undangundang, dibuatoleh atau di hadapan pegawaipegawai umum yang berkuasa untuk itu di tempat di mana akta dibuatnya. Namun ada yang berpendapat berbeda seperti apa yang disampaikan oleh Muntinah dalam thesisnya yang berjudul "Aspek Hukum Rapat Umum Pemegang Saham Perseroan Terbatas Melalui Telekonferensi" yang menyimpulkan bahwa: ${ }^{5}$

1) Mekanisme pembuatan akta dari hasil Rapat Umum Pemegang Saham yang dilakukan secara telekonferensi meliputi pembuatan akta oleh Notaris, kemudian dibacakan secara telekonferensi agar para pihak yang mengikuti RUPS dapat mengetahui isi akta. Setelah para pihak setuju dengan isi akta, kemudian dilakukan penandatanganan akta secara elektronik menggunakan digital signature. Pihak yang menandatangani adalah para pihak peserta RUPS, para saksi, dan Notaris. Semua dilakukan secara digital. Setelah penandatanganan, maka akta RUPS sudah sah dan mengikat para pihak sebagai Undang-undang.

2) Kekuatan pembuktian data digital dari Rapat Umum Pemegang Saham yang dilakukan secara telekonferensi adalah sama dengan akta RUPS yang dilakukan secara konvensional. Hal ini dikarenakan hasil RUPS secara telekonferensi sudah mendapat payung hukum dari:

a) Undang-undang Nomor 8 Tahun 1997 tentang Dokumen Perusahaan, dimana Pasal 1 angka 2 menyatakan bahwayang dimaksud dengan dokumen perusahaan adalah

5 Muntinah, Aspek Hukum Rapat Umum Pemegang Saham Perseroan Terbatas Melalui Telekonferensi, Thesis Program Studi Magister Kenotariatan Program Pascasarjana Universitas Diponegoro Semarang, 2010, Tidak dipublikasikan. 
data, catatan, dan atau keterangan yangdibuat dan atau diterima oleh perusahaan dalam rangka pelaksanaan kegiatannya, baik tertulis di atas kertas atau sarana lain maupun rekaman dalam bentuk corak apa pun yang dapat dilihat, dibaca, dan didengar. Dari ruang lingkup data yang dianggap dokumen perusahaan tersebut, dapat diketahui bahwa data rekaman dalam bentuk bukan kertas juga diakui sebagai dokumen, sehingga data hasil RUPS yang merupakan dokumen rekaman elektronik diakui keabsahannya.

b) Undang-undang Nomor 11 Tahun 2008 tentang Informasi dan Transaksi Elektronik (ITE). Dokumen elektronik berdasarkan pada Pasal 1 ayat 4 UU ITE adalah setiap informasi elektronik yang dibuat, diteruskan, dikirimkan, diterima, disimpan dalam bentuk analog, digital, elektromagnetik, optikal atau sejenisnya, yang dapat dilihat, ditampilkan dan/atau didengar melalui komputer atau sistem elektronik, termasuk tetapi tidak terbatas pada tulisan, suara, gambar, peta, rancangan, foto, atau sejenisnya, huruf, tanda, angka, kode akses, simbol, atau perforasi yang memiliki makna atau dapat dipahami oleh orang yang mampu memahaminya.

c) Selain itu, pelaksanaan RUPS dengan telekonferensi sudah diperbolehkan oleh UUPT, sehingga semakin absahlah hasil RUPS dengan telekonferensi di mata hukum.
Terlepas dari perdebatan tersebut di atas, Pasal 16 Ayat (1) huruf c Undang-undang Nomor 2 Tahun 2014 tentang Perubahan Undang-undang Nomor 30 tahun 2004 tentang Jabatan Notaris, selanjutnya mengatur bahwa Notaris wajib untuk melekatkan sidik jari penghadap pada Minuta Akta. Peneliti melihat ada konflik norma antara pasal tersebut dengan pengaturan penyelenggaraan Rapat Umum Pemegang Saham (RUPS) melalui media telekonferensi, video konferensi, atau sarana media elektronik lainnya sebagaimana yang diatur oleh Pasal 77 UUPT. Sehingga dalam penelitian ini, Peneliti merumuskan rumusan masalah sebagai berikut:

1) Bagaimana konflik norma dalam penyelenggaraan Rapat Umum Pemegang Saham Perseroan Terbatas melalui media elektronik terkait dengan kewajiban Notaris untuk melekatkan sidik jari penghadap pada minuta akta ?

2) Bagaimana implikasi yuridis terhadap Notaris dan akta Rapat Umum Pemegang Saham Perseroan Terbatas melalui media elektronik apabila Notaris tidak memenuhi kewajiban untuk melekatkan sidik jari penghadap pada minuta akta ?

Berdasarkan dengan subtansi permasalahan hukum yang hendak dikaji dalam penelitian ini, maka penelitian ini dirancang sebagai suatu penelitian yang bersifat "normatif" (dogmatik). ${ }^{6}$

6 lihat Terry Hutchinson, Researching and Writing in Law, Lawbook, Sydney, 2002, lihat juga Ian Mcleod, Legal Method, Macmilan, London, 1993. 
Untuk mengkaji permasalahan yang ada, maka penelitian ini menggunakan beberapa pendekatan yakni: statute approach (pendekatan perUndang-undangan) dan conceptual approach (pendekatan konsep). ${ }^{7}$

\section{Pembahasan}

\section{A. Konflik Norma dalam Penyelenggaraan Rapat Umum Pemegang Saham Perseroan Terbatas Melalui Media Elektronik Terkait dengan Kewajiban Notaris untuk Melekatkan Sidik Jari Penghadap pada Minuta Akta}

\section{Pengaturan penyelenggaraan rapat umum pemegang saham perseroan terbatas melalui media elektronik}

Para pemegang saham dalam rangka menyelenggarakan RUPS, dapat menyelenggarakannya di tempat kedudukan Perseroan atau ditempat Perseroan melakukan kegiatan usahanya yang utama sebagaimana ditentukan dalam anggaran dasar. Tempat RUPS tersebut harus terletak di wilayah negara Republik Indonesia. Termasuk jika dalam RUPS hadir dan/atau diwakili semua pemegang saham dan semua pemegang saham menyetujui diadakannya RUPS dengan agenda tertentu, RUPS dapat diadakan di manapun juga asalkan tetap di wilayah negara Republik Indonesia. Khusus untuk RUPS
Perseroan Terbuka dapat diadakan di tempat kedudukan bursa di mana saham Perseroan dicatatkan. ${ }^{8}$

Di dalam Pasal 77 Ayat (1) Undangundang Nomor 40 Tahun 2007 Tentang Perseroan Terbatas, terdapat pengaturan terkait penyelenggaraan RUPS yang tidak terdapat dalam Undang-undang Perseroan Terbatas sebelumnya yaitu Undang-undang Nomor 1 Tahun 1995. Pasal 77 Ayat (1) Undang-undang Nomor 40 Tahun 2007 Tentang Perseroan Terbatas mengatur sebagai berikut:

"Selain penyelenggaraan RUPS
sebagaimana dimaksud dalam Pasal
76, RUPS dapat juga dilakukan
melalui media telekonferensi,
video konferensi, atau sarana
media elektronik lainnya yang
memungkinkan semua peserta
RUPS saling melihat dan mendengar
secara langsung serta berpartisipasi
dalam rapat."

Pasal 77 Ayat (4) Undang-undang Nomor 40 Tahun 2007 Tentang Perseroan Terbatas selanjutnya mengatur bahwa:

(4) "Setiap penyelenggaraan RUPS sebagaimana dimaksud pada ayat (1) harus dibuatkan risalah rapat yang disetujui dan ditandatangani oleh semua peserta RUPS."

Yang dimaksud dengan "disetujui dan ditandatangani" adalah disetujui dan ditandatangani secara fisik atau secara elektronik.

7 Peter Mahmud Marzuki, Penelitian Hukum, Kencana, Jakarta, 2005, hlm. 93.

8 Pasal 76 ayat (1), (2), (3), (4) dan (5) Undang-undang Nomor 40 Tahun 2007 tentang Perseroan Terbatas. 


\section{Pengaturan kewajiban notaris untuk melekatkan sidik jari penghadap pada minuta akta}

Notaris sebagai pejabat umum yang berwenang untuk membuat akta autentik dan memiliki kewenangan lainnya sebagaimana dimaksud dalam Undang-undang Nomor 2 Tahun 2014 Tentang Perubahan Atas Undangundang Nomor 30 Tahun 2004 Tentang Jabatan Notaris atau berdasarkan Undangundang lainnya. ${ }^{9}$ Notaris dalam rangka menjalankan kewenangan sesuai dengan profesinya tersebut di atas harus tunduk pada kewajiban maupun larangan yang telah diatur dalam peraturan perUndang-undangan. Kewajiban menurut Kamus Lengkap Bahasa Indonesia, memiliki arti sesuatu yang harus dikerjakan (dilaksanakan). ${ }^{10}$ Sedangkan larangan menurut Kamus Lengkap Bahasa Indonesia, memiliki arti perintah (aturan) yg melarang suatu perbuatan. ${ }^{11}$

Seiring perubahan zaman yang semakin modern, yang mengikuti perkembangan masyarakat dan kemajuan ilmu pengetahuan dan tekhnologi, sehingga menimbulkan perubahan norma-norma hukum yang telah dituangkan di dalam Undang-undang, karena dianggap tidak sesuai lagi dengan nilai-nilai hukum serta tidak lagi memberikan rasa keadilan bagi masyarakat. Di dalam Undangundang Nomor 2 Tahun 2014 Tentang
Perubahan Atas Undang-undang Nomor 30 Tahun 2004 Tentang Jabatan Notaris terdapat perubahan yang mengatur kewajibankewajiban yang harus dilaksanakan seseorang Notaris, salah satunya dengan penambahan kewajiban notaris untuk melekatkan sidik jari penghadap kedalam minuta akta notaris. Kewajiban mana diatur dalam ketentuan Pasal 16 Ayat (1) huruf c Undang-undang Nomor 2 Tahun 2014 Tentang Perubahan Atas Undangundang Nomor 30 Tahun 2004 Tentang Jabatan Notaris sebagai berikut:

"Dalam menjalankan jabatannya, Notaris wajib melekatkan surat dan dokumen serta sidik jari penghadap pada Minuta Akta."

Ketentuan dalam pasal di atas menyebutkan bahwa dengan diubahnya Pasal 16 ayat (1) huruf c dalam Undang-undang Nomor 2 Tahun 2014 Tentang Perubahan Atas Undangundang Nomor 30 Tahun 2004 Tentang Jabatan Notaris, maka pembuat Undangundang memberikan kewajiban tambahan kepada para Notaris untuk melekatkan sidik jari pengahadap/para penghadap pada setiap minuta akta Notaris yang dibuat olehnya.

Latar belakang dilekatkan sidik jari penghadap pada Minuta Akta adalah untuk identifikasi kehadiran penghadap. Bukti kehadiran bahwa yang datang menghadap kepada Notaris ialah orang yang bersangkutan

9 Pasal 1 Angka 1 Undang-undang Nomor 2 Tahun 2014 tentang Perubahan Atas Undang-undang Nomor 30 Tahun 2004 tentang Jabatan Notaris.

10 Yuwono Trisno dan Pius Abdullah, Kamus Lengkap Bahasa Indonesia Praktis, Arkola, Surabaya, 1994, hlm. 463.

11 Ibid., hlm. 481. 
yang ingin membuat Akta Notaris, bukan orang lain. Diwajibkannya melekatkan sidik jari penghadap pada Minuta Akta Notaris bertujuan untuk mengantisipasi apabila suatu saat para penghadap menyangkal tanda tangannya pada Minuta Akta Notaris, maka sebagai bukti tambahan digunakan sidik jari penghadap tersebut. ${ }^{12}$

Pembuat Undang-undang menggunakan istilah "melekatkan" dan bukannya "membubuhkan". Melekatkan disini memiliki arti yang berbeda dengan membubuhkan. Melekatkan menurut Kamus Lengkap Bahasa Indonesia, memiliki arti menempelkan pada sesuatu. ${ }^{13}$ Sedangkan membubuhkan menurut Kamus Lengkap Bahasa Indonesia, memiliki arti menaruh; menambahkan; menuliskan (pada). ${ }^{14}$ Melekatkan sidik jari pada minuta akta berarti membubuhkan sidik jari pada suatu lembar kertas terpisah yang selanjutnya menempelkannya pada minuta akta.

Minuta akta itu menurut Pasal 1 Angka 8 Undang-undang Nomor 2 Tahun 2014 Tentang Perubahan Atas Undang-undang Nomor 30 Tahun 2004 Tentang Jabatan Notaris adalah asli akta yang mencantumkan tanda tangan para penghadap, saksi, dan Notaris, yang disimpan sebagai bagian dari Protokol Notaris. Disini tampak adanya inkonsistensi antara Pasal 1 Angka 8 dengan Pasal 16 Ayat (1) huruf c, dikarenakan di dalam Pasal 1 Angka 8 sama sekali tidak menyebutkan kewajiban tambahan Notaris sebagaimana diatur dalam 16 Ayat (1) huruf c, demikian untuk disimpan sebagai bagian dari Protokol Notaris.

Menurut Pasal 1868 Kitab Undangundang Hukum Perdata: "Suatu akta otentik ialah suatu akta yang dibuat dalam bentuk yang ditentukan undang- undang oleh atau dihadapan pejabat umum yang berwenang untuk itu di tempat akta itu dibuat." Dari pengertian yang terdapat dalam Pasal 1868 Kitab Undang-undang Hukum Perdata maka bentuk akta otentik ada dua, yaitu:

a. Akta Pejabat / Akta Relaas atau Akta Berita Acara, yaitu akta yang dibuat oleh (door) Pejabat Umum, berisi uraian dari Pejabat Umum yang dilihat dan disaksikan Pejabat Umum sendiri atas permintaan para pihak, agar tindakan atau perbuatan para pihak yang dilakukan dituangkan kedalam bentuk akta otentik.

b. Akta Pihak / Akta Partij, yaitu akta yang dibuat di hadapan (ten overstan) Pejabat Umum, berisi uraian atau keterangan, pernyataan para pihak yang diberikan atau yang diceritakan di hadapan Pejabat Umum. Para pihak berkeinginan agar uraian atau keterangannya dituangkan ke dalam bentuk akta otentik.

Pembuatan akta, baik akta relaas maupun akta partij, yang menjadi dasar utama atau inti dalam pembuatan akta otentik, yaitu harus ada keinginan atu kehendak (wilsvorming) dan permintaan dari para pihak, jika keinginan dan permintaan para pihak tidak ada, maka Pejabat Umum tidak akan membuat akta yang dimaksud.

12 Arief Rahman Mahmoud, Implikasi Hukum bagi Notaris yang Tidak Melekatkan Sidik Jari Penghadap pada Minuta Akta, Artikel untuk Jurnal, Tidak dipublikasikan, 2014, hlm. 19.

13 Yuwono Trisno dan Pius Abdullah, Op.cit., hlm. 259.

14 Ibid., hlm. 278. 
Penyelenggaraan RUPS dapat dituangkan dalam bentuk akta Berita Acara RUPS yang merupakan jenis kta pejabat/akta relaas maupun dalam bentuk akta Pernyataan Keputusan Rapat yang merupakan jenis akta pihak/akta partij. Dalam penyelenggaraan RUPS melalui media elektronik yang dituangkan dalam bentuk akta Pernyataan Keputusan Rapat, disini tidak ada permasalahan yang timbul dalam pelaksanaan kewajiban Notaris untuk melekatkan sidik jari pada minuta akta, dikarenakan para pemegang saham melakukan rapat internal diantara mereka dan menuangkan hasil RUPS dalam Notulen RUPS yang dibuat dibawah tangan, dimana pada akhir acara RUPS tersebut akan ditentukan siapa yang diberi kuasa (biasanya dengan hak substitusi) untu menghadap di hadapan Notaris dalam rangka menotariilkan Notulen RUPS tersebut. Sedangkan dalam penyelenggaraan RUPS melalui media elektronik yang dituangkan dalam bentuk akta Berita Acara RUPS, disini berarti Notaris ikut menghadiri dan menyaksikan jalannya rapat, sehingga disini timbul permasalahan bagi Notaris dalam pelaksanaan kewajibannya untuk melekatkan sidik jari pemegang saham/ para pemegang saham pada minuta akta, karena dimungkinkan dari para pemegang saham ada yang tidak hadir dihadapan Notaris secara langsung melainkan kehadirannya "hanya" dapat dilihat melalui media elektronik.

Obyek yang wajib dilekatkan oleh Notaris pada minuta akta adalah meliputi: surat dan dokumen serta sidik jari penghadap. Surat merupakan tulisan yang mengandung arti, baik yang dimaksudkan sebagai alat bukti maupun yang tidak dimaksudkan sebagai alat bukti, yang dibuat diatas kertas atau sarana lainnya. Sedangkan dokumen merupakan semua tulisan atau gambar yang dapat

digunakan untuk suatu kepentingan. Dengan kata lain, pengertian dokumen lebih luas jika dibandingkan dengan surat, sebab dalam dokumen termasuk gambar, foto, dan sebagainya. Melekatkan surat dan dokumen dalam minuta akta adalah merupakan hal yang sudah lazim dan seharusnya terjadi dalam pembuatan akta karena surat dan sokumen ini merupakan dokumen pendukung dari suatu akta yang didalamnya terdapat perbuatan hukum para pihak.

Sedangkan terkait dengan sidik jari, maka perlu dipahami terlebih dahulu ketentuan Pasal 44 ayat (1) dan (2) Undang-undang Nomor 2 Tahun 2014 Tentang Perubahan Atas Undang-undang Nomor 30 Tahun 2004 Tentang Jabatan Notaris juncto Pasal 46 (1) dan (2) Undang-undang Nomor 30 Tahun 2004 tentang Jabatan Notaris, sebagai berikut:

Pasal 44 Ayat (1) dan (2):

(1) "Segera setelah Akta dibacakan, Akta tersebut ditandatangani oleh setiap penghadap, saksi, dan Notaris, kecuali apabila ada penghadap yang tidak dapat membubuhkan tanda tangan dengan menyebutkan alasannya.

(2) Alasan sebagaimana dimaksud pada ayat (1) dinyatakan secara tegas pada akhir Akta." 
Pasal 46:

(1) “Apabila pada pembuatan pencatatan harta kekayaan atau berita acara mengenai suatu perbuatan atau peristiwa, terdapat penghadap yang:

a. menolak membubuhkan tanda tangannya; atau

b. tidak hadir pada penutupan akta, sedangkan penghadap belum menandatangani akta tersebut, hal tersebut harus dinyatakan dalam akta dan akta tersebut tetap merupakan akta otentik.

(2) Penolakan sebagaimana dimaksud pada ayat (1) huruf a harus dinyatakan dalam akta dengan mengemukakan alasannya."

Dari kedua pasal tersebut di atas, mengenai pembubuhan cap jempol atau ibu jari menurut penulis tidak dapat dipersamakan dengan pembubuhan tanda tangan dalam pembuatan akta notaris, oleh karena ketentuan tersebut di atas telah menegaskan bahwa akta notaris harus ditanda-tangani dan apabila para penghadap tidak dapat membubuhkan tanda tangan maka harus dijelaskan alasannya dengan jelas.

Dalam praktek Notaris mapun PPAT membubuhkan cap jempol atau ibu jari dilakukan apabila penghadap atau para penghadap tidak bisa membubuhkan tanda tangan, oleh karena tidak pernah belajar tulis baca. Cap ibu jari/cap jempol tersebut dibubuhkan di bagian akhir akta, sebagaimana diatur dalam Pasal 38 Ayat (4) Undang-undang Nomor 2 Tahun 2014 Tentang Perubahan Atas Undang-undang Nomor 30 Tahun 2004 Tentang Jabatan Notaris sebagai berikut: (4) "Akhir atau penutup Akta memuat: a. uraian tentang pembacaan Akta sebagaimana dimaksud dalam Pasal 16 ayat (1) huruf $m$ atau Pasal 16 ayat (7);

b. uraian tentang penandatanganan dan tempat penandatanganan atau penerjemahan Akta jika ada;

c. nama lengkap, tempat dan tanggal lahir, pekerjaan, jabatan, kedudukan, dan tempat tinggal dari tiap-tiap saksi Akta; dan

d. uraian tentang tidak adanya perubahan yang terjadi dalam pembuatan Akta atau uraian tentang adanya perubahan yang dapat berupa penambahan, pencoretan, atau penggantian serta jumlah perubahannya."

Pembubuhan cap jempol atau ibu jari tersebut tidak dapat diartikan sebagai pengganti tanda tangan secara hukum dalam pembuatan akta otentik. Dasar hukum cap jempol/ibu jari ditemukan di dalam Engelbrecht 1960 halaman 1753, yakni ordonansi staatsbads 1867-29 yang berjudul: Bepalingen nopens de bewjskrscht van onderhandse geschriftenvan indonesiers of met hen gelijkgestelde personen, atau dalam bahasa Indonesia: Ketentuan-ketentuan mengenai kekuatan sebagai bukti dari surat-surat dibawah tangan yang dibuat oleh golongan hukum pribumi atau orang-orang yang disamakan dengan mereka. Di dalam Pasal 1 ditentukan, bahwa cap jempol disamakan dengan tanda tangan hanya apabila cap jempol itu di-waarmerk (yang bertanggal) oleh seorang Notaris atau pejabat lain yang ditunjuk dalam ordonansi dalam keterangannya harus dinyatakan bahwa ia mengenal orang yang membubuhkan 
cap jempol atau orang itu diperkenalkan kepadanya, bahwa isi akta itu dijelaskan (voorhouden) kepada itu, setelah itu orangnya membubuhkan cap jempolnya di hadapan Notaris. Ketentuan tersebut serupa dengan yang diatur dalam Pasal 1874 Kitab Undangundang Hukum Perdata, dimana pembubuhan cap jempol yang dimaksud dalam ketentuanketentuan tersebut di atas ditujukan bagi penghadap/para penghadap yang tidak bisa tandatangan, hal mana berbeda dengan yang dimaksud dalam Pasal 16 Ayat (1) huruf c Undang-undang Nomor 2 Tahun 2014 Tentang Perubahan Atas Undang-undang Nomor 30 Tahun 2004 Tentang Jabatan Notaris.

Apabila terdapat penghadap/para penghadap yang tidak dapat membubuhkan tanda tangan dalam pembuatan akta otentik harus dijelaskan dalam akta harus dipatuhi notaris, dan apabila ketentuan tersebut dilanggar maka akta tersebut dapat kehilangan otentitasnya atau hanya mempunyai kekuatan pembuktian sebagai akta di bawah tangan serta dapat menjadi alasan bagi pihak yang menderita kerugian untuk menuntut biaya, ganti rugi dan bunga kepada Notaris, sebagaimana diatur dalam Pasal 44 Ayat (5) Undang-undang Nomor 2 Tahun 2014 Tentang Perubahan Atas Undang-undang Nomor 30 Tahun 2004 Tentang Jabatan Notaris sebagai berikut:

(5) "Pelanggaran terhadap ketentuan sebagaimana dimaksud pada ayat (1), ayat (2), ayat (3), dan ayat (4) mengakibatkan suatu Akta hanya mempunyai kekuatan pembuktian sebagai akta di bawah tangan dan dapat menjadi alasan bagi pihak yang menderita kerugian untuk menuntut penggantian biaya, ganti rugi, dan bunga kepada Notaris."

Terkait dengan keberadaan sidik jari dalam akta Notariil, yang semula hanya merupakan kebiasaan di dalam praktek Notaris mapun PPAT untuk membubuhkan cap jempol atau ibu jari hanya apabila penghadap/para penghadap tidak bisa membubuhkan tanda tangan, oleh karena tidak pernah belajar tulis baca, dengan keberadaan Pasal 16 Ayat (1) huruf c Undang-undang Nomor 2 Tahun 2014 tentang Perubahan Atas Undang-undang Nomor 30 Tahun 2004 tentang Jabatan Notaris, kini telah bergeser menjadi suatu kewajiban yang harus dilaksanakan oleh Notaris untuk melekatkan sidik jari pengahadap/para penghadap pada setiap minuta akta notaris yang dibuat olehnya. Hanya sayangnya, Undang-undang Nomor 2 Tahun 2014 tentang Perubahan Atas Undangundang Nomor 30 Tahun 2004 tentang Jabatan Notaris tidak mengatur secara jelas mengenai mekanisme melekatkan sidik jari penghadap pada minuta akta, sehingga kekaburan norma (vague van normen) pun terjadi dan tentu saja menimbulkan kebingungan dalam pelaksanaannya.

Terkait kewajiban untuk melekatkan sidik jari penghadap pada Minuta Akta, belum terjadi kesepakatan di antara para Notaris, padahal Undang-undang Jabatan Notaris telah secara tegas mengaturnya. Pengurus Pusat Ikatan Notaris Indonesia (PP INI) Adrian Djuaini (Ketua Umum), Arry Supratno, Abdul Syukur, beranggapan bahwa "sidik 
jari” tersebut wajib dilekatkan pada Minuta Akta Notaris untuk seluruh penghadap, baik penghadap yang bisa membubuhkan tanda tangan, maupun yang tidak bisa membubuhkan tanda tangan. Mereka menyampaikan bahwa: ${ }^{15}$

"Bahwa sekalipun bagi penghadap yang tidak bisa bertanda tangan dapat diganti dengan surogat (lembaga pengganti tanda tangan), namun mengenai bukti kehadiran penghadap di hadapan Notaris, sidik jari dipandang perlu, apalagi Undang-undang Jabatan Notaris telah mengaturnya, terutama apabila satu-satunya penghadap atau seluruh penghadap tidak bisa membubuhkan tanda tangannya. Alat bukti tersebut adalah sidik jari penghadap, sekalipun akta autentik yang bersangkutan sudah merupakan alat bukti otentik."

Meskipun telah dilaksanakan beberapa sosialisasi baik oleh Kementerian maupun PP INI pasca diundangkannya Undang-undang Nomor 2 Tahun 2014 Tentang Perubahan Atas Undang-undang Nomor 30 Tahun 2004 Tentang Jabatan Notaris, tetapi kekaburan norma (vague van normen) yang terjadi di beberapa pasal termasuk pada Pasal 16 Ayat (1) huruf c, menimbulkan kebingungan dalam pelaksanaannya. Kebingungan tersebut disikapi oleh PP INI dengan menyampaikan kesatuan sikap diantaranya yang menyatakan bahwa yang digunakan adalah cap ibu jari kanan saja. Selain itu sidik jari tersebut diambil berkaitan dengan pembuatan akta tertentu (diambil pada setiap pembuatan akta yang dibuat dalam bentuk minuta akta), yang diambil pada lembaran kertas tersendiri dengan memuat uraian yang jelas judul akta, tanggal akta, nomor akta, nama penghadap dan bila dirasa perlu dikuatkan dengan tandatangan dari penghadap kemudian dilekatkan pada minuta akta. Sidik jari tersebut diambil pada hari dan tanggal yang sama dihadapan Notaris dan saksi-saksi pada saat berlangsungnya proses pembuatan akta dan sebelum penandatanganan akta. ${ }^{16}$

Notaris yang tidak memenuhi kewajiban untuk melekatkan sidik jari penghadap pada Minuta Akta sebagaimana diatur dalam Pasal 16 Ayat (1) huruf c Undang-undang Nomor 2 Tahun 2014 Tentang Perubahan Atas Undangundang Nomor 30 Tahun 2004 Tentang Jabatan Notaris tersebut, dapat dikenai sanksi berupa: ${ }^{17}$
a. peringatan tertulis;
b. pemberhentian sementara;
c. pemberhentian dengan hormat; atau
d. pemberhentian dengan tidak hormat.

15 PP INI, Seminar Nasional, Membangun Hukum Kenotariatan di Indonesia, Yogyakarta, 27 Februari 2014. 16 Ibid.

17 Pasal 16 Ayat (11) Undang-undang Nomor 2 Tahun 2014 tentang Perubahan Atas Undang-undang Nomor 30 Tahun 2004 tentang Jabatan Notaris. 
3. Konflik norma dalam pengaturan penyelenggaraan rapat umum pemegang saham perseroan terbatas melalui media elektronik terkait dengan kewajiban notaris untuk melekatkan sidik jari penghadap pada minuta akta

Latar belakang dilekatkan sidik jari penghadap pada Minuta Akta adalah untuk identifikasi kehadiran penghadap. Bukti kehadiran bahwa yang datang menghadap kepada Notaris ialah orang yang bersangkutan yang ingin membuat Akta Notaris, bukan orang lain. Diwajibkannya melekatkan sidik jari penghadap pada Minuta Akta Notaris bertujuan untuk mengantisipasi apabila suatu saat para penghadap menyangkal tanda tangannya pada Minuta Akta Notaris, maka sebagai bukti tambahan digunakan sidik jari penghadap tersebut. ${ }^{18}$

Hal senada juga disampaikan oleh Notaris senior, Alwesius, bahwa latar belakang dibuatnya ketentuan yang mengatur mengenai kewajiban melekatkan sidik jari tersebut menurut Alwesius adalah untuk memperkuat pembuktian mengenai pembuatan suatu akta agar penghadap/para pengadap tidak mudah lagi untuk membantah adanya pembuatan dan penandatanganan akta tersebut dihadapan Notaris. Jika ini latar belakangnya maka untuk tercapainya maksud tersebut menurut
Alwesius, harus ada 4 (empat) hal yang harus dipastikan berkaitan dengan pelekatan sidik jari tersebut, yaitu: ${ }^{19}$

1. Sidik jari tersebut benar berasal dari jari penghadap yang bersangkutan;

2. Sidik jari tersebut bersumber langsung dari jari tangan penghadap, dalam arti tidak melalui perantara media lainnya;

3. Sidik jari tersebut diambil berkaitan dengan pembuatan akta tertentu;

4. Sidik jari tersebut diambil pada saat mulai berlangsungnya proses pembuatan akta dan sebelum penandatangan akta.

Keempat hal tersebut menurut Penulis tidak akan bisa terpenuhi ketika Notaris membuat akta Berita Acara RUPS yang diselenggarakan melalui media elektronik.

Penulis disini berpendapat bahwa terdapat adanya konflik norma yaitu dalam bentuk disharmonisasi dalam pengaturan penyelenggaraan RUPS PT melalui media elektronik sebagaimana diatur dalam Pasal 77 Ayat (1) dan (4) Undang-undang Nomor 40 Tahun 2007 Tentang Perseroan Terbatas dengan pengaturan terkait kewajiban notaris untuk melekatkan sidik jari penghadap pada minuta akta sebagaimana diatur dalam Pasal 16 Ayat (1) huruf c Undang-undang Nomor 2 Tahun 2014 Tentang Perubahan Atas Undangundang Nomor 30 Tahun 2004 Tentang Jabatan Notaris. pada Minuta Akta, Artikel untuk Jurnal, Tidak dipublikasikan, 2014, hlm. 19. 
Pasal 77 Ayat (1) dan (4) Undang-undang Nomor 40 Tahun 2007 Tentang Perseroan Terbatas mengatur hal sebagai berikut:

Ayat (1): "Selain penyelenggaraan RUPS sebagaimana dimaksud dalam Pasal 76, RUPS dapat juga dilakukan melalui media telekonferensi, video konferensi, atau sarana media elektronik lainnya yang memungkinkan semua peserta RUPS saling melihat dan mendengar secara langsung serta berpartisipasi dalam rapat."

Ayat (4): "Setiap penyelenggaraan RUPS sebagaimana dimaksud pada ayat (1) harus dibuatkan risalah rapat yang disetujui dan ditandatangani oleh semua peserta RUPS."

Penjelasan Pasal 77 Ayat (4) menjelaskan bahwa yang dimaksud dengan "disetujui dan ditandatangani" adalah disetujui dan ditandatangani secara fisik atau secara elektronik.

Artinya meskipun bentuk persetujuan dari para pemegang saham yang tidak hadir secara nyata di dalam RUPS telah diberikan melalui mekanisme penandatanganan secara elektronik (digital signature). Tapi terkait pelaksanaan kewajiban Notaris sebagaimana diatur dalam Pasal 16 Ayat (1) huruf c Undang-undang Nomor 2 Tahun 2014 Tentang Perubahan Atas Undang-undang Nomor 30 Tahun 2004 Tentang Jabatan Notaris sebagai berikut:

"Dalam menjalankan jabatannya, Notaris wajib melekatkan surat dan dokumen serta sidik jari penghadap pada Minuta Akta."
Maka kewajiban tersebut menurut Penulis akan mustahil untuk dilaksanakan.

Perlu diingat kembali, bahwa terkait dengan tanda tangan elektronik memang telah diatur dalam Pasal 1 Angka 12 Undang-undang Nomor 11 Tahun 2008 Tentang Informasi Dan Transaksi Elektronik, bahwa yang dimaksud dengan

Tanda Tangan Elektronik adalah tanda tangan yang terdiri atas Informasi Elektronik yang dilekatkan, terasosiasi atau terkait dengan Informasi Elektronik lainnya yang digunakan sebagai alat verifikasi dan autentikasi.

Pasal 11 Ayat (1) Undang-undang Nomor 11 Tahun 2008 Tentang Informasi Dan Transaksi Elektronik juncto Pasal 53 Peraturan Pemerintah Nomor 82 Tahun 2012 Tentang Penyelenggaraan Sistem Dan Transaksi Elektronik mengatur bahwa Tanda Tangan Elektronik memiliki kekuatan hukum dan akibat hukum yang sah selama memenuhi persyaratan sebagai berikut:

a. data pembuatan Tanda Tangan Elektronik terkait hanya kepada Penanda Tangan;

b. data pembuatan Tanda Tangan Elektronik pada saat proses penandatanganan elektronik hanya berada dalam kuasa Penanda Tangan;

c. segala perubahan terhadap Tanda Tangan Elektronik yang terjadi setelah waktu penandatanganan dapat diketahui;

d. segala perubahan terhadap Informasi Elektronik yang terkait dengan Tanda Tangan Elektronik tersebut setelah waktu penandatanganan dapat diketahui; 
e. terdapat cara tertentu yang dipakai untuk mengidentifikasi siapa Penandatangannya; dan

f. terdapat cara tertentu untuk menunjukkan bahwa Penanda Tangan telah memberikan persetujuan terhadap Informasi Elektronik yang terkait.

Undang-undang ini memberikan pengakuan secara tegasbahwa meskipun hanya merupakan suatu kode. Tanda Tangan Elektronik memiliki kedudukan yang sama dengan tanda tangan manual pada umumnya yang memiliki kekuatan hukum dan akibat hukum. Persyaratan sebagaimana dimaksud dalam Pasal tersebut di atas merupakan persyaratan minimum yang harus dipenuhi dalam setiap Tanda Tangan Elektronik. Ketentuan ini membuka kesempatan seluas luasnya kepada siapa pun untuk mengembangkan metode, teknik, atau proses pembuatan Tanda Tangan Elektronik.

Sebenarnya tekhnologi yang berkembang saat ini juga telah mengenal adanya sidik jari elektronik atau yang biasa dikenal dengan istilah fingerprint. Sayangnya terkait keberadaan sidik jari elektronik belum diakomodir di dalam Undang-undang Nomor 11 Tahun 2008 Tentang Informasi Dan Transaksi Elektronik. Sehingga menurut Penulis disini, keberadaan sidik jari elektronik tidak bisa dipersamakan dengan tanda tangan elektronik. Disini menurut Penulis konflik norma yang terjadi adalah kekosongan norma yang mengatur mengenai sidik jari elektronik di dalam Undang-undang Nomor 11 Tahun
2008 Tentang Informasi Dan Transaksi Elektronik.

B. Implikasi Yuridis terhadap Notaris dan Akta Rapat Umum Pemegang Saham Perseroan Terbatas Melalui Media Elektronik Apabila Notaris Tidak Memenuhi Kewajiban untuk Melekatkan Sidik Jari Penghadap Pada Minuta Akta

Pasal 16 ayat (1) huruf c Undang-undang Nomor 2 Tahun 2014 Tentang Perubahan Atas Undang-undang Nomor 30 Tahun 2004 Tentang Jabatan Notaris mengatur mengenai kewajiban Notaris untuk melekatkan surat dan dokumen serta sidik jari penghadap pada Minuta Akta. Sehingga ketika Notaris dalam membuat akta Berita Acara RUPS PT yang pelaksanaannya melalui media elektronik dan kemudian dikarenakan hal tersebut, Notaris menjadi tidak dapat memenuhi kewajibannya untuk melekatkan sidik jari penghadap/para penghadap pada minuta akta, maka Notaris dapat dikenai sanksi sesuai pasal 16 ayat (11) Undang-undang Nomor 2 Tahun 2014 Tentang Perubahan Atas Undang-undang Nomor 30 Tahun 2004 Tentang Jabatan Notaris, yaitu:

1) peringatan tertulis

2) pemberhentian sementara

3) pemberhentian dengan hormat

4) pemberhentian dengan tidak hormat

Sanksi yang terdapat dalam Pasal 16 ayat (11) Undang-undang Nomor 2 Tahun 2014 Tentang Perubahan Atas Undangundang Nomor 30 Tahun 2004 Tentang Jabatan Notaris, atas pelanggaran pasal 16 
ayat (1) huruf c Undang-undang Nomor 2 Tahun 2014 Tentang Perubahan Atas Undangundang Nomor 30 Tahun 2004 Tentang Jabatan Notaris dapat dikategorikan sebagai sanksi administratif. Sanksi ini merupakan sanksi terhadap Notaris yang berkaitan dengan akta yang dibuatnya, dikarenakan dalam menjalankan tugas jabatannya, Notaris tidak memenuhi kewajiban-kewajibannya sebagaimana telah diatur dalam Undangundang Nomor 2 Tahun 2014 Tentang Perubahan Atas Undang-undang Nomor 30 Tahun 2004 Tentang Jabatan Notaris.

Sanksi administratif dapat dibedakan 3 (tiga) macam, yaitu: ${ }^{20}$

1) Sanksi reparatif, sanksi ini ditujukan untuk perbaikan atas pelanggaran tata tertib hukum. Dapat berupa penghentian perbuatan terlarang, kewajiban perubahan sikap/tindakan sehingga tercapai keadaan semula yang ditentukan, tindakan memperbaiki sesuatu yang berlawanan dengan aturan. contohnya paksaan untuk berbuat sesuatu untuk pemerintah dan pembayaran uang paksa yang ditentukan sebagai hukuman.

2) Sanksi punitif, sanksi yang bersifat menghukum, merupakan beban tambahan, sanksi hukuman tergolong dalam pembalasan, dan tindakan preventif yang menimbulkan ketakutan kepada pelanggar yang sama atau mungkin untuk pelanggar-pelanggar lainnya. contohnya, pembayaran denda kepada pemerintah, teguran keras.

3) Sanksi regresif sanksi sebagai reaksi atas suatu ketidaktaatan, dicabutnya hak atas sesuatu yang diputuskan menurut hukum, seolah-olah dikembalikan kepada keadaan hukum yang sebenarnya sebelum keputusan diambil. Contohnya: pencabutan, perubahan atau penangguhan suatu keputusan.

Di dalam beberapa kepustakaan hukum administrasi dikenal beberapa jenis sanksi administratif, antara lain: ${ }^{21}$

1) Eksekusi nyata, sanksi ini digunakan administrasi, baik dengan tidak memenuhi kewajiban yang tercantum dalam suatu ketetapan hukum-hukum administrasi maupun pada pelanggaranpelanngaran suatu ketentuan Undangundang, berbuat tanpa izin, yang terdiri dari me ngambil, menghalangi, menjalankan atau memperbaiki apa yang bertentangan dengan ketentuanketentuan dalam peraturan-peraturan yang sah, yang dibuat, disusun, dialami, dibiarkan dirusak atau diambil oleh pelaku.

2) Eksekusi langsung (parate executie), sanksi dalam penagihan uang yang berasal dari hubungan hukum-hukum administrasi.

20 Habib Adjie, Hukum Notaris Indonesia, Refika Aditama, Bandung, 2008, hlm. 211.

21 Ibid., hlm. 212. 
3) Penarikan kembali suatu izin, sanksi yang diberikan pada pelanggaran peraturan atau yang berhubungan dengan ketetapan, tetapi juga pelanggaran peraturan perUndang-undangan.

Sanksi-sanksi yang terdapat pada Pasal 16 ayat (11) Undang-undang Nomor 2 Tahun 2014 Tentang Perubahan Atas Undang-undang Nomor 30 Tahun 2004 Tentang Jabatan Notaris, dilihat dari urutannya tampak berlakunya secara berjenjang mulai dari peringatan tertulis sampai dengan pemberhentian dengan tidak hormat. Penjatuhan sanksi-sanksi tersebut dilakukan apabila Notaris terbukti melanggar ketentuan Pasal 16 Ayat (1) huruf a sampai dengan 116 ayat (11) Undang-undang Nomor 2 Tahun 2014 Tentang Perubahan Atas Undang-undang Nomor 30 Tahun 2004 Tentang Jabatan Notaris.

Fungsi melekatkan sidik jari dalam minuta akta Notaris bukan suatu tindakan hukum dalam menentukan keabsahan atau otentisitas dari akta tersebut melainkan hanya berfungsi untuk menjamin kebenaran identitas penghadap. Notaris diharuskan melaksanakan kewajibannya tersebut dalam menjalankan profesinya sebagai Notaris, apabila tidak akan dikenakan sanksi administratif.

\section{Simpulan}

1. Selain konflik norma berupa kekaburan norma di dalam Pasal 16 ayat Undang-undang Nomor 2 Tahun 2014 tentang Perubahan Atas Undangundang Nomor 30 Tahun 2004 tentang
Jabatan Notaris mengenai kewajiban Notaris untuk melekatkan sidik jari para penghadap pada minuta akta.

Konflik norma juga terjadi dalam penyelenggaraan Rapat Umum Pemegang Saham Perseroan Terbatas melalui media elektronik terkait dengan kewajiban Notaris untuk melekatkan sidik jari penghadap pada minuta akta, yaitu adanya disharmonisasi yang terjadi antara Pasal 77 Ayat (1) dan (4) Undangundang Nomor 40 Tahun 2007 tentang Perseroan Terbatas dengan Pasal 16 ayat (11) Undang-undang Nomor 2 Tahun 2014 tentang Perubahan Atas Undangundang Nomor 30 Tahun 2004 tentang Jabatan Notaris.

Selain itu juga terdapat kekosongan norma yang mengatur mengenai sidik jari elektronik di dalam Undang-undang Nomor 11 Tahun 2008 tentang Informasi dan Transaksi Elektronik.

2. Implikasi yuridis terhadap Notaris dan akta Rapat Umum Pemegang Saham Perseroan Terbatas melalui media elektronik apabila Notaris tidak memenuhi kewajiban untuk melekatkan sidik jari penghadap pada minuta akta adalah:

a. ketika Notaris dalam membuat akta Berita Acara RUPS PT yang pelaksanaannya melalui media elektronik dan kemudian dikarenakan hal tersebut, Notaris menjadi tidak dapat memenuhi kewajibannya untuk 
melekatkan sidik jari penghadap/ para penghadap pada minuta akta, maka Notaris dapat dikenai sanksi sesuai pasal 16 ayat (11) Undangundang Nomor 2 Tahun 2014 tentang Perubahan Atas Undang-undang Nomor 30 Tahun 2004 tentang Jabatan Notaris, yaitu:

1) peringatan tertulis

2) pemberhentian sementara

3) pemberhentian dengan hormat

4) pemberhentian dengan tidak hormat b. Fungsi melekatkan sidik jari dalam minuta akta Notaris bukan suatu tindakan hukum dalam menentukan keabsahan atau otentisitas dari akta tersebut melainkan hanya berfungsi untuk menjamin kebenaran identitas penghadap. Notaris diharuskan melaksanakan kewajibannya tersebut dalam menjalankan profesinya sebagai Notaris, apabila tidak akan dikenakan sanksi administratif.

\section{DAFTAR PUSTAKA}

Buku

C.S.T. Kansil, Christine S.T. Kansil, 2009, Seluk Beluk Perseroan Terbatas Menurut Undang-undang No. 40

Tahun 2007, Rineka Cipta, Jakarta.

Darwan Prinst, 1998, Strategi Menyusun dan Menangani Gugatan Perdata, Citra Aditya Bakti, Bandung.

Edmon Makarim, 2007, Pengantar Hukum

Telematika, RajaGrafindo Persada, Jakarta.

Gatot Supramono, 2009, Hukum Perseroan

Terbatas, Djambatan, Jakarta.

G.H.S. Lumban Tobing, 1999, Peraturan

Jabatan Notaris, Jakarta, Erlangga.

Habib Adjie, 2008, Hukum Notaris

Indonesia, Tafsir Tematik terhadap

UU No. 30 Tahun 2004 tentang

Jabatan Notaris, Refika Aditama,

Bandung.
Handri Raharjo, 2009, Hukum Perusahaan, Pustaka Yustisia, Yogyakarta.

H.M.N. Purwosatjipto, 1982, Pengertian Pokok Hukum Dagang Indonesia, Jilid 2, Djambatan, Jakarta.

Ifa H. Misbach, 2010, Dahsyatnya Sidik Jari, Visimedia, Jakarta.

I.G Rai Widjaya, 2002, Hukum Perseroan

Terbatas (Edisi Revisi), Jakarta, Megapoint Kesant Blanc.

Jamin Ginting, 2007, Hukum Perseroan Terbatas (UU No. 40 Tahun 2007), Citra Aditya Bakti, Bandung.

Johny Ibrahim, 2006, Teori dan Metode Penelitian Hukum Normatif, Bayumedia, Malang.

M. Yahya Harahap, 2009, Hukum Perseroan

Terbatas, Sinar Grafika, Jakarta.

M. Karjadi, Sidik, 1976, Jari Sistem Hendry (Sistem Baru yang Diperluas), Politeia, Bogor. 
Munir Fuady, 2002, Perseroan Terbatas

Paradigma Baru, Citra Aditya Bhakti,

Bandung.

Peter Mahmud Marzuki, 2005, Penelitian

Hukum, Kencana, Jakarta.

Rachmadi Usman, 2004, Dimensi Hukum

Perseroan Terbatas, Bandung,

Alumni.

Rochmat Soemitro, 1993, Hukum Perseroan

Terbatas, Yayasan dan Wakaf,

Eresco, Bandung.

Sudikno Mertokusumo, 1981, Hukum

Acara Perdata Indonesia, Liberty, Yogyakarta.

Suyadi, 2010, Rahasia Sidik Jari, Flash Books, Yogjakarta.

Walter Moon dalam M. Yahya Harahap, 2009,

Hukum Perseroan Terbatas, Sinar Grafika, Jakarta.

\section{Makalah}

Muntinah, 2010, Aspek Hukum Rapat Umum Pemegang Saham Perseroan Terbatas Melalui Telekonferensi,
Thesis Program Studi Magister Kenotariatan Program Pascasarjana Universitas Diponegoro Semarang, Tidak dipublikasikan.

\section{Peraturan Perundang-undangan}

Kitab Undang-undang Hukum Perdata (KUHPerdata).

Kitab Undang-undang Hukum Dagang (KUHD).

Undang-undang Nomor 30 tahun 2004 tentang Jabatan Notaris.

Undang-undang Nomor 40 Tahun 2007 tentang Perseroan Terbatas.

Undang-undang Nomor 11 Tahun 2008 tentang Informasi dan Transaksi Elektronik.

Undang-undang Nomor 2 Tahun 2014 tentang Perubahan Undang-undang Nomor 30 tahun 2004 tentang Jabatan Notaris.

Peraturan Pemerintah Nomor 82 Tahun 2012 tentang Penyelenggaraan Sistem dan Transaksi Elektronik. 